\title{
EMPIRICAL RESEARCH OF USERS' OPINIONS ON SELECTED ASPECTS IN INTERNET FINANCIAL REPORTING
}

\author{
Mohd Noor Azli Ali Khan, Noor Azizi Ismail, Abbas Mardani, \\ Edmundas Kazimieras Zavadskas, Arturas Kaklauskas
}

\section{Introduction}

This paper analyzes on the perceptions of internet financial reporting (hereinafter referred to as IFR) in Malaysia. While internet financial reporting is fast and attractive becoming the standard in developed countries, but, few of previous studies have focused on this phenomenon in developing countries. In recent years internet usage have increased for dissemination of corporate information and is seen as a globalization process (Moradi et al., 2011; Gallego-Alvarez, 2011; Valentinetti \& Rea, 2012). In addition, the system of economic digitalized (Shiri et al., 2013). Thus, disclosure of financial reporting represents continuing improvement over traditional methods such as paper based in terms of supplying timely data, lower cost and speed in obtaining information about corporations (Ojah \& Mokoteli, 2012; Andrikopoulos et al., 2013). Moreover, paperbased annual reports are less useful now in terms of timeliness and reliability as the world is highly reliant on information and communication technologies (Ettredge et al., 2002). Internet connection has several directions in nature and very rapid in transmission and offers increased accessibility to financial and non-financial information (Bollen et al., 2008; Sanchez et al., 2011). Many companies around the world are motivated to practice IFR to meet users' needs for more timely information (Amin \& Mohamed, 2016).

According to current IFR literature, evolution of IFR is the significant topic in studies. The IFR research evolution can classified in the various descriptive researches, themes, dimensions of IFR, association researches and classification of IFR. In addition; the study on IFR can categories in different types such as; descriptive study some countries, study by scholars and explanatory study. (Ali Khan, 2010). Furthermore; studies on IFR can be categorized based on first and second generation (Al-Htaybat, 2011). Although; previous studies have emphasized on IFR researches in last two decades, few of previous papers have focused and descript the relationship between attitudes and preferences of corporate annual report user and corporate behaviour particularly in developing countries such as Malaysia. As well, the success of electronic government policy in Malaysia has increased the number of companies that utilize internet financial reporting in both the public and private sectors (Abdul Aziz et al., 2011). This is because companies had realized the benefits associated with IFR (Poon et al., 2003). Firms which are adopting the internet for accounting and financial information presentation may see additional benefits over additional costs by providing financial reports through a website (Khan, 2006). In addition, the development of information technology makes a revolution in achieve information outside of around the world (Shiri et al., 2013). According to Ali Khan et al. (2013), content dimension is an important factor to influence the effectiveness of IFR as the items of IFR will help to determine the importance and usefulness of IFR in Malaysia. Also, there are several motivations in engaging IFR in Malaysia which are an increase in the transparency of disseminating company information, increased use of the internet in terms of promotion and the creation of a good brand name as well as the practise of good corporate governance (Kiew \& Salleh, 2011). There are no guidelines prescribing the information on corporate websites (Ali Khan \& Ismail, 2011a). Yet, there are still no mandatory guidelines and requirement for IFR disclosure in Malaysia (Hanifa \& Ab. Rashid, 2005). Therefore, the aim of this study to examine the 
perceptions of corporate annual report users towards selected aspects of IFR in Malaysia.

The remainder of this article is organized as follows. A review of relevant literature are provided in the next section. Section two discusses the research design, followed by research findings. Next section describes web usage and web content analytics. A summary, conclusion and suggestions for future research are presented in the final section.

\section{Internet Financial Reporting and Web Analytics - Review of the Literature}

IFR is an interesting, attractive and rapid growing study field (Oyelere et al., 2003; Xiao et al., 2005; Ali Khan, 2010; Andrikopoulos et al., 2013). According to Stoel et al. (2012), most companies have started to adopt IFR with the advance of information technology. Although IFR are wider issues to study, the implementation is different across countries in terms of technological development, and the tendency to use the internet for financial reporting purposes and significantly influenced by the accounting system in each country (Alali \& Romero, 2012). Ojah and Mokoteli (2012) stated that political environment is one of the factors which have contributed to corporate adoption of IFR. Researcher also provided examples from studies which indicated that five East Asia countries including Hong Kong, Malaysia, Thailand, Singapore and China which lack complementary environment infrastructure has not successfully adopted IFR overall. In addition, IFR also promotes transparency about information disclosure which enhances managerial decisions and the congruency of stakeholders in the decision making process (Kelton \& Pennington, 2012; Ojah \& Mokoteli, 2012).

Lymer (1999) indicated that, there are some benefits of the the internet for financial reporting such as flexibility,speed, its cheapness and dynamism, On the other hand, internet has become effective by promoting the use of hyperlinks and search engines (Ojah \& Makoteli, 2012). From an investor's perspective, Kelton and Pennington (2012) stated that IFR is another way of accessing information which will influence their decision making process based on the information disclosed. In addition, IFR not only contain the financial reporting as paper based reports. It also reports current situations in a format which enhances accessibility and flexibility toward users (Ojah \& Mokoteli, 2012).

Benefit in terms of cost associated with the flexibility provided by hyperlink make IFR more interactive and more user friendly (Kelton \& Pennington, 2012). Other than that, the introduction of a new technology like IFR requires expertise. Thus, the implementation, compliance and the quality of the overall financial reporting disclosure may be less effective due to the lack of expertise (Stoel et al., 2012; Shiri et al., 2013).

In the recent years the important of IFR issues have confirmed in the literature. Moradi et al. (2011) stated that IFR is a new, significant and interesting area for future studies and has become a focus of urgent investigation at international level (Al-Htaybat, 2011). The results of this emerging stream of IFR research suggest that companies are still in the very preliminary stages of integrating these technologies into their overall communication strategy (Bowrin, 2015). The level of IFR of Bursa Malaysia listed companies started from 48.27 per cent to 78.16 per cent with a min of 65.10 (Ali Khan, 2011a). Furthermore, the level of IFR among the public listed companies in Bursa Malaysia started from 56.43 per cent to 87.14 per cent (Ali Khan, 2015). The disclosure items in the IFR disclosure index checklist are based on the perspective of users of corporate annual report (Ali Khan, 2016). Content analysis is used to provide on IFR practices by 280 publicly traded firms. Based on the Ali Khan (2016), the level of IFR of Bursa Malaysia listed companies started from 56.55 per cent to 86.21 per cent.

Also, we analyze Web analytics (Web usage and Web content analytics) to discover financial and non-financial usage and content patterns from company websites and other sources of World data. Web usage analytics has allowed company creates better buyer relationship and to do personalized marketing. For example, we can used Open Web Analytics (OWA). OWA is an open source web analytics software that anyone can use that software to track and analyse how people use your websites and applications.

Web Content Mining focuses on the raw information available in Web pages. Source data mainly consists of textual data in Web pages. Many Web Content mining systems for the discovering company revenue relations 
from news (Ma et al., 2009), predicting company (Thorleuchter et al., 2012), firm analysis (Cecchini et al., 2010), opinion mining (Moreo et al., 2012; He et al., 2015; Ravi et al., 2015; Mostafa, 2013), predictability of financial (Nassirtoussi et al., 2014) and stock (Schumaker \& Chen, 2009; Groth \& Muntermann, 2011; Paranjape-Voditel \& Deshpande, 2013; Zhang et al., 2011; Fortuny et al., 2014; Schumaker et al., 2012) markets, competitor analysis (Ma et al., 2011) have been developed worldwide. The following is a short description of some of the Web Content Mining systems for discover financial and non-financial usage and content patterns from company websites and other sources of World data.

Cecchini et al. (2010) for examine of company catastrophic financial events have used financial text. Cecchini et al. (2010) found that fraud $(81.97 \%)$ and bankruptcy $(83.87 \%)$ with the integrated data, representing that the text of the management discussion and analysis sections complements the quantitative financial information. Mostafa (2013) showed the significant of some social networks such as Facebook and Twitter hav been important in marketing firms, public firms and some other text mining corporations. Mostafa (2013) to assess the consumers' sentiment towards utilized the random sample of 3516 tweets of famus brands like T-mobile, DHL, IBM, KLM and Nokia.

Nassirtoussi et al. (2014) review the related works that are about market prediction based on online-text-mining and produce a picture of the generic components that they all have. Schumaker and Chen (2009) examine a quantitative stock prediction system based on financial news. Schumaker and Chen (2009) seek to contribute to the Arizona Financial Text System (AZFinText) by comparing AZFinText's predictions against existing quantitative funds and human stock pricing experts.

Zhang et al. (2011) describe early work trying to predict stock market indicators such as Dow Jones, NASDAQ and S\&P 500 by analyzing Twitter posts. Zhang et al. (2011) measured collective hope and fear on each day and analyzed the correlation between these indices and the stock market indicators. Zhang et al. (2011) found that emotional tweet percentage significantly negatively correlated with Dow Jones, NASDAQ and S\&P 500, but displayed significant positive correlation to VIX. Fortuny et al. (2014) discuss how to gain insight into text-mining-based stock price prediction models in order to evaluate, validate and refine the models.

\section{Research Design}

The main goal of this paper to examines the perceptions of corporate annual report users toward in the several perspectives of IFR. To date, few of previous papers have been the examine perceptions and attitudes of users of corporate annual report and compare them to selected aspects of IFR provided by corporations in Malaysia. As far as we aware, this is among the first study to evaluate and compare the selected aspects of IFR of various user-groups in Malaysia.

For this objective we have collected require data through means of survey questionnaire. Respondents of this paper were a corporate annual report user. Mohd Isa (2006) stated that perspectives of annual report users (academicians, business owners, graduates, share broker and other public users) are familiar with financial information, accounting information and have knowledge for using the information in the corporate annual report. In addition; academics are selected for the proxy group of the corporate annual report users in our paper because they are considered to be responsible for system of accounting education (Mishekary \& Saudagaran, 2005). Furthermore; auditors are selected because they using the financial information, financial reporting and accounting information to finalized the performance of company. Mohd Isa (2006) indicated that; students believed can be as group for corporate annual report users because of their academic specialization and background. Bank officers are representatives of a market economy (Mirshekary \& Saudagaran, 2005). Moreover; managers were selected as another group because they are considers being responsible for daily decision making which influence on business process. (Barsky \& Catanach, 2011; Moghadam et al., 2013). The respondents were asked to indicate their opinions on a five-point Likert scale ranging from $1=$ not important at all to $5=$ very important.

The nature of this paper is exploratory which can conducted for examine the perception of the preliminary respondents. We sent questionnaire for the respondents and a letter for introduce of study objective, confidentiality 
of the respondent, a stamped addressed envelope and availability of survey result upon request. Questionnaire of this study is used to collect their ideas on different IFR aspects including; advantages, disadvantages, factors and benefits. For examine the important of IFR items the perception survey of user-group was conducted. Tab. 1 shows the respondents questionnaire which pooled opinions on the level of importance of each disclosure item in the list for content and presentation dimension. 308 questionnaires out of 490 sent were returned (62.86 per cent).

The questionnaire of this study was including two sections. The first section was related to respondents' information including education level and major, sex and age. The second part consists of respondents' perception towards advantages, disadvantages, factors and benefits of IFR.

To provide the study issues in the second part of the questionnaire, we employed the test of Kruskal-Wallis for the selected aspects of IFR.
The Kruskal-Wallis and Mann-Withney $U$ tests were chosen as being appropiate for testing the hypothesis in section part of the questionnaire (similar with Mirshekary \& Saudagaran, 2005). Mirshekary and Saudagaran (2005) stated that to showing the weights of each group were similar, determine if the weightings of each group were similar, Mann-Withney $U$ and KruskalWallis test have used for testing hypothesis. For examine the individual information items such questionnaire which give the decision making parties like a standard setting board, regulator and professional scholars, a better insight into agreement and desirability or difference that would be between users groups and into each group (Mirshekary \& Saudagaran, 2005). Therefore, a Kruskal-Wallis test was used on second part of the questionaire to test the significant differences among the users for each information item. Furthermore, a Mann-Withney $U$ test was carried out to find differences between user-groups (Mirshekary \& Saudagaran, 2005).

\begin{tabular}{c|l|l} 
Tab. 1: Distribution of respondents & \multicolumn{1}{c}{ Respond } \\
No. & \multicolumn{1}{c|}{ User Group } & \multicolumn{1}{c}{ (106 out of $150=67 \%$} \\
\hline 1 & Manager & 34 out of $50=68 \%$ \\
\hline 2 & Academic & 54 out of $110=49 \%$ \\
\hline 3 & Bank officer & 74 out of $80=93 \%$ \\
\hline 4 & Student & 40 out of $100=40 \%$ \\
\hline 5 & Auditor & $\mathbf{3 0 8}$ Malaysian respondents \\
\hline & Total &
\end{tabular}

Source: own research on perceptions of Internet Financial Reporting

\section{Research Findings}

According to findings of Tab. 2, the percentages of 308 respondents, 129 (41.9\%) respondents were male and female were 179 (58.1\%) respondents. In terms of academic qualification 140 respondents had the diploma holders, degree were 108 respondents, master and PhD were 51 and nine respectively. 173 of our respondents had 30 years, 34 of our respondents were between ages 41 to 50 , 89 of respondents had age between 31 to 40 years old, and 12 respondents were 51 above years old. In terms of academic specialization, major of 200 respondents were accounting,
33 respondents were finance, 26 including accounting and finance, and 36 respondents were business administration, nine of respondents were in economic major and four respondents focused on investment. In terms of organization position, 106 of our respondents were managers, academics respondents were 34 , university students were 74,54 work as bank officers $(17.5 \%)$ and finally 40 work as auditor (13.0\%).

In order to determine the benefits that may accrue to companies which disclose their annual reports to the public through internet, respondents asked nine items to demonstrated 
Tab. 2: Profile of respondent

\begin{tabular}{|c|c|c|c|}
\hline Demographic & Item & Frequency & $\begin{array}{c}\text { Percentage } \\
(\%)\end{array}$ \\
\hline \multirow[t]{2}{*}{ Gender } & Male & 129 & 41.9 \\
\hline & Female & 179 & 58.1 \\
\hline \multirow[t]{4}{*}{ Age } & $<30$ years & 173 & 56.2 \\
\hline & $31-40$ years & 89 & 28.9 \\
\hline & $41-50$ years & 34 & 11.0 \\
\hline & $51-60$ years & 12 & 3.9 \\
\hline \multirow[t]{4}{*}{ Academic qualification } & Diploma & 140 & 45.5 \\
\hline & Degree / Professional & 108 & 35.1 \\
\hline & Master & 51 & 16.6 \\
\hline & $\mathrm{PhD}$ & 9 & 2.9 \\
\hline \multirow[t]{6}{*}{ Majoring } & Accounting & 200 & 64.9 \\
\hline & Finance & 33 & 10.7 \\
\hline & Accounting \& Finance & 26 & 8.4 \\
\hline & Investment & 4 & 1.3 \\
\hline & Economic & 9 & 2.9 \\
\hline & Business Administration & 36 & 11.7 \\
\hline \multirow[t]{5}{*}{ Position in organization } & Academic respondents & 34 & 11 \\
\hline & University Students & 74 & 24.0 \\
\hline & Manager & 106 & 34.4 \\
\hline & Bank Officer & 54 & 17.5 \\
\hline & Auditor & 40 & 13.0 \\
\hline
\end{tabular}

Source: own research on perceptions of Internet Financial Reporting

agreements' level of each item shown. Tab. 3 represented; overall the users determined an average usefulness mean above 3.5 to each of nine items which shows all the items are significant and relevant.

Furthermore, attract foreign investor was first choice followed by promote company wider to the public, attract local investors, provide wider coverage, attract potential customers, enhance managerial efficiency and discharge accountability are significant at one percent, while no item was significant at five percent. Usually, by disclosing an annual report through internet all users can access and analyze the financial report of that company, so if the company financial report has a good background it will attract foreign investors and the possibility of increased future profit.
Findings of Kruskal Wallis test demonstrated that; there are differences in the user groups' perception about whether the appearance of an annual report through internet would improve the financial performance of the company. The test of Mann Whitney indicated that the perception on prepared is different from the user perception. They differed based on the prepared perception during preparation of the annual report. Users can actually use other annual reports from other companies as a guide line to prepare their own annual report that they can then improve and measure. Subsequently, unlike user perception they only use annual report to analyze the data without making corrections or adjustments so it does not impact their perception regarding whether or not it will improve financial performance. 
Finally, promote transparency differed from the preparers and users on the dimension concerning benefit to the company. Regarding user perception company disclosure of their annual report to the public through internet is the best action to allow users a easier method to analyze the company performance because of their transparency. Consequently, from preparers' perception, promotion of transparency to the public would increase the security problem regarding the safety of their annual report in future.
The study sought opinions from the respondents on the perception when disclose annual report through internet based on benefit to users. The list of items namely increase efficiency and timeliness in achieving inexpensively, information regarding financial, makes investment decision process faster, helps users in the decision making process and easier, provides accessibility to the users, provides another medium of disclosure and information for company. The findings of this section were presented in Tab. 4.

\section{Tab. 3: Benefits to company}

\begin{tabular}{|c|c|c|c|c|c|}
\hline \multirow{2}{*}{ Item } & \multirow{2}{*}{ Mean } & \multirow{2}{*}{ Std. Dev. } & \multirow{2}{*}{ Rank } & \multicolumn{2}{|c|}{ Kruskal Wallis test } \\
\hline & & & & $x^{2}$ & Sig. \\
\hline \multicolumn{6}{|l|}{ Great importance } \\
\hline Attract foreign investors & 4.30 & .727 & 1 & 24.335 & $.000^{* *}$ \\
\hline Promote company more wider to the public & 4.24 & .754 & 2 & 36.183 & $.000^{\star *}$ \\
\hline Attract local investors & 4.18 & .732 & 3 & 26.810 & $.000^{\star *}$ \\
\hline Provide wider coverage & 4.18 & .728 & 4 & 26.357 & $.000^{* *}$ \\
\hline Attract potential customers & 4.13 & .791 & 5 & 18.970 & $.001^{* *}$ \\
\hline Promote transparency & 4.08 & .790 & 6 & 9.274 & .055 \\
\hline Enhance managerial efficiency & 4.04 & .820 & 7 & 30.158 & $.000^{* *}$ \\
\hline Discharge accountability & 4.04 & .800 & 8 & 15.895 & $.003^{\star \star}$ \\
\hline \multicolumn{6}{|l|}{ Moderate importance } \\
\hline Improve financial performance & 3.92 & .847 & 9 & 8.781 & .067 \\
\hline
\end{tabular}

Source: own research on perceptions of Internet Financial Reporting

${ }^{*} \operatorname{sig} 5 \% ;{ }^{* *} \operatorname{sig} 1 \%(1=$ not important at all; $5=$ very important $)$

We can see from the table that six items shown were considered of great important at all. According to this results we can predict the facts that disclose annual report through internet is being beneficial to users directly when they used it. Thus, the result received shows all items are relevance and exceed the mean 4.00 above.

Continuously, interestingly the most important item from the users' perception was "increase efficiency and timeliness in achieving of financial information" with the highest in this dimension mean 4.15. This indicates that user group very concern about timeliness and efficiency to get their information on annual report. It is not surprising because most of the user group consists of the working people and some students and they need the information quickly fulfill their purpose such as their research and etc. Thus, the content in annual report must be updated and this is quite difficult to prepare and measure it. However, the updated annual report can avoid complaint from users and maintain their reputation.

The second most important source of perception was make investment decision process easier and faster. According to investor perception for example, the needed to analyze the performance of the company that they want to invest. Thus, for those companies who have enough information and always update their annual report, it will be easier and faster for investor to make decision in investment or business to that company in the future. The 


\begin{tabular}{|c|c|c|c|c|c|}
\hline \multirow{2}{*}{ Item } & \multirow{2}{*}{ Mean } & \multirow{2}{*}{ Std. Dev. } & \multirow{2}{*}{ Rank } & \multicolumn{2}{|c|}{ Kruskal Wallis tes } \\
\hline & & & & $x^{2}$ & Sig. \\
\hline \multicolumn{6}{|l|}{ Great importance } \\
\hline Provides another medium of disclosure & 4.03 & .715 & 6 & 14.403 & $.006^{* *}$ \\
\hline $\begin{array}{l}\text { Provides information for company, } \\
\text { inexpensively }\end{array}$ & 4.10 & .841 & 3 & 24.803 & $.000^{\star *}$ \\
\hline $\begin{array}{l}\text { Makes investment decision process easier } \\
\& \text { faster }\end{array}$ & 4.13 & .788 & 2 & 31.120 & $.000^{* *}$ \\
\hline Provides accessibility to the users & 4.10 & .784 & 4 & 29.160 & $.000^{\star *}$ \\
\hline $\begin{array}{l}\text { Increase efficiency and timeliness in achieving } \\
\text { of financial information }\end{array}$ & 4.15 & .770 & 1 & 27.547 & $.000^{* *}$ \\
\hline Helps users in the process of decision making & 4.06 & .831 & 5 & 18.891 & $.001^{* *}$ \\
\hline
\end{tabular}

Source: own research on perceptions of Internet Financial Reporting

${ }^{*}$ sig 5\%; ** sig 1\% (1 = not important at all; 5 = very important $)$

findings of Kruskal Wallis test demonstrated that; regarding to user groups regarding there are no significant differences among the perception related to the users benefits and other items can be classified as relevance and significant.

This study attempted to get opinions from the respondents on the significant of the factors influences companies to practice IFR. There are 11 items asked to the respondent and the result shows only four items are significant at one percent. Meanwhile, all items are relevance with exceed mean 3.50 and only three items exceed mean 4.00. The results shows all items will categorized as great importance shown in Tab. 5.

Interestingly, the most important source of perception with the highest mean 4.21 is to enhance corporate image. It shows that company will get good reputation if they advertise their annual report to the public because the entire users can access their information easier thus contribute to enhance corporate image. Perhaps, it will attract people such as attract foreign investor in Tab. 3 when the company are known in public. Next, competitor in the industry would contribute company to more competitive to announce their annual report through internet. As we know the main purpose to establish the company is to minimize the wealth and make the profit so to measure it the company must give the best service from other companies. Thus, competitors in the industry influence the companies the most to practice IFR.

The resutls of Kruskal Wallis test found that there are significant differences among user group of their view of all the items in Tab. 5 and Mann Whitney tested illustrated significant difference regarding the items show. The result of ten items are categorized as significant from the eleven items were asked to the respondents.

The study has also investigated the factors which contributed to companies not practicing IFR. Thus, respondents were asked to determine the extent to which the items are factors which motivate companies not to practice IFR. The questionnaire introduced 11 possible reasons and the findings are presented in Tab. 6 .

The Tab. 6 showed that; there are some reasons presented for respondents are deemed moderately important and only one item as of great importance. The first three items are needed to company expertise, required to keep update information and concern over security of information. Basically, implementing a new system into the company will incur financial costs and the required expertise to develop it. Thus, some companies don't have onsite staff with the expertise needed to operate the system during and after implementation. The least importance reason was fear of losing competitive advantage.

The results of Kruskal Wallis test showed that there are significant difference between the user groups only regarding the most importance 


\begin{tabular}{|c|c|c|c|c|c|}
\hline \multirow{2}{*}{ Item } & \multirow{2}{*}{ Mean } & \multirow{2}{*}{ Std. Dev. } & \multirow{2}{*}{ Rank } & \multicolumn{2}{|c|}{ Kruskal Wallis test } \\
\hline & & & & $x^{2}$ & Sig. \\
\hline \multicolumn{6}{|l|}{ Great importance } \\
\hline Improve corporate image & 4.21 & .751 & 1 & 17.222 & $.002^{* *}$ \\
\hline $\begin{array}{l}\text { Company speaker with the develop of } \\
\text { technology }\end{array}$ & 4.11 & .813 & 2 & 15.228 & $.004^{* *}$ \\
\hline Industry Competitors & 4.06 & .774 & 3 & 20.634 & $.000^{\star *}$ \\
\hline \multicolumn{6}{|l|}{ Moderate importance } \\
\hline Obligations to community & 3.89 & .764 & 4 & 5.505 & .239 \\
\hline Stability and improvement in share prices & 3.88 & .855 & 5 & 17.696 & $.001^{* *}$ \\
\hline Receive government support & 3.84 & .841 & 6 & 7.322 & .120 \\
\hline Obtain funds from wider sources & 3.82 & .825 & 7 & 6.620 & .177 \\
\hline Directors desire to engage IFR & 3.80 & .813 & 8 & 2.619 & .623 \\
\hline Media attention & 3.74 & .887 & 9 & 3.271 & .514 \\
\hline Pressures from stakeholders & 3.66 & .868 & 10 & 3.061 & .548 \\
\hline Win awards & 3.46 & .914 & 11 & 8.268 & .082 \\
\hline
\end{tabular}

Source: own research on perceptions of Internet Financial Reporting

${ }^{*} \operatorname{sig} 5 \% ;{ }^{* *} \operatorname{sig} 1 \%(1=$ not important at all; $5=$ very important $)$

\section{Tab. 6: Factors which influence a company not to engage IFR}

\begin{tabular}{|c|c|c|c|c|c|}
\hline \multirow{2}{*}{ Item } & \multirow{2}{*}{ Mean } & \multirow{2}{*}{ Std. Dev. } & \multirow{2}{*}{ Rank } & \multicolumn{2}{|c|}{ Kruskal Wallis test } \\
\hline & & & & $x^{2}$ & Sig. \\
\hline \multicolumn{6}{|l|}{ Great importance } \\
\hline Required expertise from the company & 4.00 & .783 & 1 & 2.732 & .604 \\
\hline \multicolumn{6}{|l|}{ Moderate importance } \\
\hline Too costly to setup and maintain & 3.75 & .926 & 5 & 2.247 & .690 \\
\hline $\begin{array}{l}\text { Concern over disclosure of proprietary } \\
\text { information }\end{array}$ & 3.82 & .795 & 4 & 6.780 & .148 \\
\hline Do not want to be too transparent & 3.71 & .958 & 6 & 7.069 & .132 \\
\hline Need to keep information updated to be of use & 3.96 & .788 & 2 & 9.363 & .053 \\
\hline $\begin{array}{l}\text { There are alternative forms of obtaining } \\
\text { information }\end{array}$ & 3.70 & .811 & 7 & 2.296 & .681 \\
\hline Cost incurred outweigh benefits to company & 3.71 & .958 & 8 & 1.655 & .799 \\
\hline Potential legal liability & 3.69 & .875 & 9 & 5.387 & .250 \\
\hline Concern over security of information & 3.87 & .887 & 3 & 3.966 & .411 \\
\hline No legal requirement & 3.68 & .936 & 10 & 15.290 & $.004^{* *}$ \\
\hline Fear of losing competitive advantage & 3.57 & .915 & 11 & 8.041 & .090 \\
\hline
\end{tabular}

${ }^{*} \operatorname{sig} 5 \% ;{ }^{*} \operatorname{sig} 1 \%(1=$ not important at all; 5 = very important $)$ 
reason, which is no legal requirement. As a result only one item which is no legal requirement is significant at $1 \%$. Mostly, all the companies are very concerned about the security of information and this leads a company to decide not to practice IFR. Even though, companies try to minimize the availability of sensitive information about the company on the internet, sometimes other people can manipulate the data without company knowledge.

In order to determine the content of annual report, it is important that companies know the advantages or disadvantages of distributing their annual report through internet. This action is important to ensure that unexpected problems do not arise later, and for companies to be aware of this potential problem in advance. As shown in Tab. 7, all seven items display an average usefulness mean above 3.5 on each of the advantages of IFR. As a result, respondent agrees that the greatest advantage of IFR is increased information (downloadable) and analysis (mean of 4.19). It is because the more information about the company the user has, the better will be the analysis of the company.

The finding shows that the advantage of IFR in terms of increased global reach and mass communication came second in importance while navigational ease, increased timeliness and up-date ability, and interaction and feedback were recorded as the most important with a mean exceeding 4.00. Thus, all items shows significant amounts compared to other items in Tab. 7.

Kruskal Wallis test indicated that user group differed significantly in their perception about the advantage of IFR. The Mann Whitney test illustrated that every user has a different perception regarding the advantage of IFR in relation to presentation flexibility and visibility and cost benefit. It is because for the preparer these criteria are still significant but for the user, it is not the main advantage of IFR.

The study has also investigated the disadvantages of IFR in terms of implementation and shows what the constraint deal with it. Thus, the questionnaire introduced six possible reasons and respondents were asked to rank them based in terms of importance based on their perception and understanding. The results are shown in Tab. 8.

The finding revealed that the six possible reasons introduced to respondents were of great to moderate importance. Only one item was categorized as of great importance namely security problems. As companies, advertise their annual report over the internet the data are dangerously expose to anybody that has the skill or technique to destroy the system or sabotage the company for their purpose. All the items in Tab. 8 are still relevant when mean exceeds 3.5.

Kruskal Wallis test revealed significant differences between the user groups and the

Tab. 7:

Advantages of IFR

\begin{tabular}{l|c|c|c|c|c}
\multicolumn{1}{c|}{ Item } & \multirow{2}{*}{ Mean } & Std. Dev. & Rank & \multicolumn{4}{c}{ Kruskal Wallis test } \\
\cline { 4 - 7 } & & & & $\mathbf{X}^{2}$ & Sig. \\
\hline Great importance & 4.17 & .755 & 2 & 22.776 & $.000^{* *}$ \\
\hline Global reach and mass communication & 4.03 & .801 & 5 & 5.720 & .221 \\
\hline Interaction and feedback & 4.06 & .771 & 4 & 12.929 & $.012^{*}$ \\
\hline Timeliness and up-date ability & 4.19 & .718 & 1 & 12.664 & .013 \\
\hline $\begin{array}{l}\text { Increased information (downloadable) and } \\
\text { analysis }\end{array}$ & 4.09 & .763 & 3 & 21.356 & $.000^{* *}$ \\
\hline Navigational ease & & & & & \\
\hline Moderate importance & 3.91 & .822 & 7 & 9.795 & $.044^{*}$ \\
\hline Cost beneficial & 3.95 & .777 & 6 & 5.325 & .256 \\
\hline Presentation flexibility and visibility &
\end{tabular}

Source: own research on perceptions of Internet Financial Reporting

${ }^{*} \operatorname{sig} 5 \% ;{ }^{* *} \operatorname{sig} 1 \%(1=$ not important at all; 5 = very important) 


\begin{tabular}{|c|c|c|c|c|c|}
\hline \multirow{2}{*}{ Item } & \multirow{2}{*}{ Mean } & \multirow{2}{*}{ Std. Dev. } & \multirow{2}{*}{ Rank } & \multicolumn{2}{|c|}{ Kruskal Wallis test } \\
\hline & & & & $\mathrm{x}^{2}$ & Sig. \\
\hline \multicolumn{6}{|l|}{ Great importance } \\
\hline Security problems & 4.02 & .839 & 1 & 4.533 & .339 \\
\hline \multicolumn{6}{|l|}{ Moderate importance } \\
\hline Cost and expertise & 3.96 & .824 & 2 & 8.193 & .085 \\
\hline Developed and developing country digital divide & 3.83 & .846 & 3 & 9.331 & .053 \\
\hline Poor website design and advertising & 3.75 & .866 & 4 & 16.510 & $.002^{* *}$ \\
\hline $\begin{array}{l}\text { Authentication, attestation and legal } \\
\text { impediments }\end{array}$ & 3.74 & .838 & 5 & 13.304 & $.010^{* *}$ \\
\hline Information overload & 3.72 & .927 & 6 & 11.406 & $.022^{*}$ \\
\hline
\end{tabular}

Source: own research on perceptions of Internet Financial Reporting

${ }^{*} \operatorname{sig} 5 \% ;{ }^{* *} \operatorname{sig} 1 \%(1=$ not important at all; $5=$ very important $)$

result shows most of the items are categorized as significant. As a result, Mann Whitney are revealed to test the differences. Most company's faced the problem of limitations in cost and expertise to run this system in their company, because sometimes companies have to pay expert staff to run the software and this will incur some cost.

\section{Web Usage and Web Content Analytics}

The following is a short description of two case studies in the Web analytics field developed by authors:

\section{Case Study: Are current trends} in the housing market positive, negative, or neutral?

Can words used and attitudes expressed in reviews by housing market analysts correlate with changes the housing market is undergoing? We use text analytics (Kaklauskas, 2015; Kaklauskas et al., 2014) to identify and extract information on residential property prices from different online financial reviews. Our goal is to define the approach of an observer with respect to housing prices and discover patterns in financial reviews that could explain increased housing market risk. In our case study, one main purpose is the classification of the polarity of the financial texts - whether the stated view on the current Dublin housing market trends is positive, negative, or neutral. We analyze Burke-Kennedy's and Pope's (2016) reviews on housing prices in Dublin. All words of their analysis are clustered into neutral (normalisation, unchanged), negative (lower, fell, fall, decline, down, wipe, overheating, collapse, volatility) and positive (higher, up, rising, rise, rose, climb, will run, growth, climb). We emphasise the polarity classification between positive and negative words. We apply a polarity scaling system for negative, neutral or positive business text on a 0 to 100 scale (from most negative to most positive). Words that describe the present housing market (overheating, collapse) are very significant and get bigger weight. The findings of our text analytics show a moderate negative market viewpoint $(60.46 \%)$ towards the housing market.

\section{Case Study: Web data mining in broker websites}

At present the developed Web-Based Negotiation and Decision Support System for Real Estate (DSS-RE) help to increase of the performance of five main functions including; determination of the most rational real estate purchase variant, search for real estate alternatives; negotiations and $f$ analysis of alternatives; In order to throw more light on the DSS-RE, a more detailed description of some of the above-mentioned Subsystem functions follows. A consumer may perform a search for real estate alternatives from databases from 
different brokers. Search results for a specific real estate are submitted in a textual, photo/ video, augmented reality and graphical information on the real estate's alternatives and the initial negotiation table, which include direct links to a Web page of brokers. When submitting such a display, the multiple criteria comparisons and e-negotiations can become more effectively supported. While going through the purchasing decision process a customer should examine a large number of alternatives, each of which is surrounded by a considerable amount of information/knowledge (economic, qualityarchitectural, aesthetic, comfort, infrastructure, technical, legal, technological), and other factors. Following on from the gathered information and knowledge, the multiple criteria analysis and e-negotiations (Kaklauskas et al., 2005; Urbanavicienè et al., 2009) are then carried out. By using multiple criteria methods as was developed by the authors, the buyer (broker) determines the initial priority, utility degree and market value of the analyzed real estate's alternatives during this analysis and e-negotiations.

\section{Conclusions}

The major aim of this paper to investigated the perceptions of corporate annual report users based on various aspects of IFR such as benefits, factors, advantages and disadvantages of IFR. Few of previous studies emphasized on IFR practices in the developing countries such as Malaysia, therefore this research is an early study for fill this gap of our knowledge. It is hoped that the research findings will spark future studies related to IFR research. There are three significant findings can be as basis for future studies. First, the respondents ranked the four most important ways that IFR implementation benefits companies including the ability to attract foreign investors, promote the company to a wider public, attract local investors and provide wider coverage. Furthermore, there are three benefits for user groups who gather the company's financial information through their webpage including are to the users who collect financial information of companies via their website are: and efficiency in obtaining financial information, increases timeliness, faster, and provides an inexpensive way to disseminate information about the company and makes investment decision process easier. The second benefit was related to technology development company teller, the corporate image enhancement, and industry competitors as the three important elements which impact on companies for adopting of the IFR. On the other side, needed expertise from the companies, required to keep update information for using, and concern over information security were the three significant elements which inhibited companies from adopting of IFR. Third, the results indicated that increase analysis and information, mass communication and globe reach have been the significant advantages of IFR. In addition; expertise, cost and security problems were the main disadvantages of IFR.

As mentioned earlier, there is a need to further improve financial reporting disclosure and standardization must be made to have specific rules that can minimize some IFR issues. In conclusion, a checklist of disclosure items for IFR is important to ensure IFR is an attractive way to obtain information. The current paper can be considered as one of the initial research papers in the area of selected aspects of IFR and thus it provides some contributions. Nevertheless, the limitation and issues should be taken into consideration to minimize the problems and some improvements should be done to enhance the usefulness of IFR in the future. Furthermore, accurate information disclosed by the company's website presented in Bursa Malaysia's listed companies should be able to assist users in making investment decisions and would also be significant to the auditors' practices. Also, we analyze Web analytics (Web usage and Web content analytics) to discover financial and non-financial usage and content patterns from company websites and other sources of World data. The case studies submitted in this article partly demonstrates the developed Web analytics systems.

The financial support for the authors' research from Ministry of Higher Education (MOHE), Malaysia, Research Management Center (RMC), Universiti Teknologi Malaysia, Johor Bahru, Johor, Malaysia and Faculty of Management, Universiti Teknologi Malaysia, Johor Bahru, Johor, Malaysia also appreciated. The authors also gratefully acknowledge the contribution of Ho Shuang Tien, Norhayati Salleh and Nurul Ain Omar for completing this manuscript. 


\section{References}

Abdelsalam, O. H., Bryant, S. M., \& Street, D. L. (2007). An examination of comprehensiveness of corporate internet reporting provided by London-Listed Companies. Journal of International Accounting Research, 6(2), 1-33. doi:10.2308/jiar.2007.6.2.1.

Abdelsalam, O. H., \& Street, D. L. (2007). Corporate governance and the timeliness of corporate internet reporting by U.K. listed companies. Journal of International Accounting, Auditing and Taxation, 16(2), 111-130. doi:10.1016/j.intaccaudtax.2007.06.001.

Abdul Aziz, A., Mohd Arrifin, N. N., \& Mohamed, I. S. (2011). Internet financial reporting in Malaysia. International Proceedings of Computer Science and Information Technology, 3, 302-306.

Alali, F., \& Romero, S. (2012). The use of the Internet for corporate reporting in the Mercosur (Southern common market): The case Argentina case. Advance in Accounting, Incorporating Advances in International Accounting, 28(1), 157-167. doi:10.1016/j.adiac.2012.03.009.

Al-Htaybat, K. (2011). Corporate online reporting in 2010: a case study in Jordan. Journal of Financial Reporting \& Accounting, 9(1), 5-26. doi:10.1108/19852511111139778.

Ali Khan, M. N. A., \& Ismail, N. A. (2008a). An evolution of internet financial reporting research. In International Accounting and Business Conference (IABC) 2008. Puteri Pan Pacific, Johor Bahru, Johor, August 18-19.

Ali Khan, M. N. A., \& Ismail, N. A. (2008b). Faktor, kelebihan dan kekurangan pelaporan kewangan menerusi internet: satu kajian awal. In National Management Conference (NaMac) 2008, Primula Beach Resort, Kuala Terengganu, Terengganu, December 13-14.

Ali Khan, M. N. A., \& Ismail, N. A. (2009). Internet financial reporting in Malaysia, factors, pros and cons. Accountants Today, 22(2), 28-31.

Ali Khan, M. N. A., \& Ismail, N. A. (2011a). The Level of Internet Reporting of Malaysian Companies. Asian Journal of Accounting and Governance, 2, 27-39.

Ali Khan, M. N. A., \& Ismail, N. A. (2011b). The use of disclosure indices in internet financial reporting research. Journal of Global Business and Economics, 3(1),157-173.

Ali Khan, M. N. A. (2015). Internet Financial Reporting in Malaysia: Preparers' and Users' Perceptions. Procedia - Social and Behavioral Sciences, 172, 778-785. doi:10.1016/j.sbspro.2015.01.432.

Ali Khan, M. N. A. (2016). Disclosure Items of Internet Financial Reporting: Malaysian Users Perceptions. International Business Management, 10(18), 4090-4097. doi:10.3923/ ibm.2016.4090.4097.

Ali Khan, M. N. A., Ismail, N. A., \& Zakuan, N. (2013). Benefits of internet financial reporting in a developing countries: Evidence from Malaysia. African Journal of Business Management, 7(9), 719-726.

Allam, A., \& Lymer, A. (2003). Development in internet financial reporting: review and analysis across five developed countries. The International Journal of Digital Accounting Research, 3(6),165-199.

Amin, H. M. G., \& Mohamed, E. K. A. (2016). Auditors' perceptions of the impact of continuous auditing on the quality of Internet reported financial information in Egypt. Managerial Auditing Journal, 31(1), 111-132. doi:10.1108/MAJ-01-2014-0989.

Andrikoppoulos, A., Merika, A. A., Triantafyllou, A., \& Merkas, A. G. (2013). Internet disclosure and corporate performance: a case study of the international shipping industry. Transportation Research, 47, 141152. doi:10.1016/j.tra.2012.10.016.

Ashbaugh, H., Johnstone, K. M., \& Warfield, T. D. (1999). Corporate reporting on the internet. Accounting Horizons, 13(3), 241-257. doi:10.2308/acch.1999.13.3.241.

Barsky, N. P., \& Catanach, A. H. (2011). Every manager can be an innovator. Strategic Finance, 93(2), 22-29.

Bollen, L. H., Hassink, H. F., Lange, R. K. D., \& Buijl, S. D. (2008). Best practices in managing investor relations websites: Directions for future research. Journal of Information System, 22(2), 171-194. doi:10.2308/jis.2008.22.2.171.

Bonson, E., \& Escobar, T. (2002). A survey on voluntary disclosure on the internet: empirical evidence from 300 European union companies. The International Journal of Digital Accounting Research, 2(1), 27-51.

Bonson, E., Escobar, T., \& Flores, F. (2006). Online transparency of banking sector. Online Information Review, 30(6), 714-730. doi:10.1108/14684520610716180.

Brennan, N., \& Hourigan, D. (1998). Corporate reporting on the internet by Irish companies. Accountancy Ireland, 30(6),18-21. 
Browrin, A. R. (2015). Comprehensiveness of internet reporting by Caribbean companies. Journal of Accounting in Emerging Economics, 5(1), 2-34. doi:10.1108/JAEE-08-2011-0028.

Burke-Kennedy, E., \& Pope, C. (2016). House prices fall again in wake of new lending restrictions. The Irish time.

Cecchini, M., Aytug, H., Koehler, G. J., \& Pathak, P. (2010). Making words work: Using financial text as a predictor of financial events. Decision Support Systems, 50(1), 164-175. doi:10.1016/j.dss.2010.07.012.

Chan, W. K., \& Wickramasinghe, N. (2006). Using the internet for financial disclosure: the Australian experience. International Journal Electronic Finance, 2(1), 118-150. doi:10.1504/IJEF.2006.008841.

Chen, Y. H., Wu, J. J., \& Chang, H. T. (2013). Examining the mediating effect of positive moods on trust repair in e-commerce. Internet Research, 23(3), 355-371. doi:10.1108/10662241311331772.

Craven, B. M., \& Marston, C. L. (1999). Financial reporting on the Internet by leading UK companies. The European Accounting Review, 8(2), 321-333. doi:10.1080/096381899336069.

Davey, H., \& Homkajohn, K. (2004). Corporate internet reporting: an asian example. Problems and Perspectives in Management, 2, 211-227.

de Fortuny, E. J., de Smedt, T., Martens, D., \& Daelemans, W. (2014). Evaluating and understanding text-based stock price prediction models. Information Processing \& Management, 50(2), 426-441. doi:10.1016/j.ipm.2013.12.002.

Debreceny, R., Gray, G. L., \& Rahman, A. (2002). The determinants of internet financial reporting. Journal of Accounting and Public Policy, 21(4-5), 371-394. doi:10.1016/S0278-4254(02)00067-4.

Deller, D., Stubenrath, M., \& Weber, C. (1999). A survey on the use of the internet for investor relations in the USA, the UK and Germany. The European Accounting Review, 8(2), 351-364. doi:10.1080/096381899336087.

Ettredge, M., Richardson, V. J., \& Scholz, S. (2001). The presentation of financial information at corporate Web sites. International Journal of Accounting Information Systems, 2(3), 149-168. doi:10.1016/S1467-0895(00)00017-8.

Ettredge, M., Richardson, V. J., \& Scholz, S. (2002). Dissemination of information for investors at corporate Web sites. Journal of
Accounting and Public Policy, 21(4-5), 357-369. doi:10.1016/S0278-4254(02)00066-2.

FASB. (2000). Business reporting research project: electronic distribution of business reporting information. Steering Committee Report Series Financial Accounting Standards Board.

FASB. (2001). Improving business reporting: Insights into enhancing voluntary disclosures. Financial Accounting Standards Board.

Fisher, R., Oyelere, P., \& Laswad, F. (2004). Corporate reporting on the internet audit issues and content analysis of practices. Managerial Auditing Journal, 19(3), 412-439. doi:10.1108/02686900410524418.

Gallego-Alvarez, I., Rodriguez, L., \& Garcia-Sanchez, I. M. (2011). Information disclosed online by Spanish universities: content and explanatory factors. Online Information Review, 35(3), 360-385. doi:10.1108/14684521111151423.

Garg, M. C., \& Verma, D. (2010). Web-based corporate reporting practices in India. The IUP Journal of Accounting Research \& Audit Practices, 9(3), 7-19. doi:10.2139/ssrn.2160612.

Green, G., \& Spaul, B. (1997). Digital accountability. Accountancy, International Edition, 49-50 May.

Griffiths, P. (2012). Information Audit: Towards Common Standards and Methodology. Business Information Review, 29(1), 39-51. doi:10.1177/0266382112436791.

Groth, S. S., \& Muntermann, J. (2011). An intraday market risk management approach based on textual analysis. Decision Support Systems, 50(4), 680-691. doi:10.1016/j.dss.2010.08.019.

Hanifa, M. H., \& Ab Rashid, H. (2005). The determinants of voluntary disclosures in Malaysia: the case of internet financial reporting. UNITAR E-Journal, 2(1), 22-42.

Haniffa, M. H., \& Ab Rashid, H. (2004). The determinants of voluntary disclosures in Malaysia: The case of internet financial reporting. In International Business Management Conference 2004, Kuantan, Pahang, December 6-7.

Hassan, S., Jaaffar, N., Johl, S. K., \& Mat Zain, M. N. (1999). Financial reporting on the internet by Malaysian companies: perceptions and practices. Asia-Pacific Journal of Accounting, 6(2), 299-319. doi:10.1080/10293 574.1999.10510567. 
He, W., Wu, H., Yan, G., Akula, V., \& Shen, J. (2015). A novel social media competitive analytics framework with sentiment benchmarks. Information \& Management, 52(7), 801-812. doi:10.1016/j.im.2015.04.006.

Healy, P. M., \& Palepu, K. G. (2001). Information asymmetry, corporate disclosure, and the capital market: a review of the empirical disclosure literature. Journal of Accounting and Economics, 31(1-3), 405-440. doi:10.1016/S0165-4101(01)00018-0.

Hindi, N. M., \& Rich, J. (2010). Financial reporting on the internet: evidence from the fortune 100. Management Accounting Quarterly, 11(2), 11-21.

Ho, S. S. M., \& Wong, K. S. (2001). A study of the relationship between corporate governance structures and the extent of voluntary disclosure. Journal of International Accounting, Auditing \& Taxation, 10(2), 139-156. doi:10.1016/S1061-9518(01)00041-6.

Ho, S. S. M., \& Wong, K. S. (2003). Preparers' perceptions of corporate reporting and disclosure. International Journal of Disclosure and Governance, 1(1), 71-81. doi:10.1057/palgrave.jdg.2040014.

ICAEW. (2004). Digital reporting: a progress report. London: The Institute of Chartered Accountants in England and Wales.

IFAC. (2002). Financial reporting on the internet. International Federation of Accountants.

Jiambalvo, J. (2004). Managerial Accounting (2nd ed.). USA: John Wiley \& Sons, Inc.

Jones, M. J., \& Xiao, J. Z. (2004). Financial reporting on the Internet by 2010: a consensus view. Accounting Forum, 28(3), 237-263. doi:10.1016/j.accfor.2004.07.002.

Joshi, P. L., \& Al-Modhahki, J. (2003). Analytics on the internet: Empirical evidence from Bahrain and Kuwait. Asia-Pacific Journal of Accounting, 11(1), 88-101.

Kaklauskas, A. (2015). Biometric and Intelligent Decision Making Support. In Series: Intelligent Systems. Reference Library, XII. Berlin: Springer-Verlag.

Kaklauskas, A., Zavadskas, E. K., \& Andruskevicius, A. (2005). Cooperative integrated support system negotiation and decision support system for real estate. Lecture notes in computer science 3675 (pp. 235-242). Berlin: Springer-Verlag.

Kaklauskas, A., Seniut, M., Amaratunga, D., Lill, I., Safonov, A., Vatin, N., Cerkauskas, J., Jackute, I., Kuzminske, A., \& Peciure, L.
(2014). Text Analytics for Android Project. Procedia Economics and Finance, 18, 610-617. doi:10.1016/S2212-5671(14)00982-4.

Kelton, A. S., \& Pennington, R. R. (2012). Internet financial reporting: The effects of information presentation format and content differences on investor decision making. Computers in Human Behavior, 28(4), 1178-1185. doi:10.1016/j.chb.2012.01.028.

Kelton, A. S., \& Yang, Y. (2008). The impact of corporate governance on Internet financial reporting. Journal of Accounting and Public Policy, 27(1), 62-87. doi:10.1016/j.jaccpubpol.2007.11.001.

Khan, T. (2006). Financial reporting disclosure on the internet: an international perspective (Unpublished doctoral dissertation). Victoria University, Footscray Park Victoria, Australia.

Kiew, H. Y., \& Salleh, Z. (2011). Internet financial reporting in Malaysia: the preparers' view. Asian Journal of Finance and Accounting, 3(1), 138-161. doi:10.5296/ajfa.v3i1.1067.

Liu, L. G. (2000). The emergence of business information resources and services on the Internet and its impact on business librarianship. Online Information Review, 24(3), 234-255. doi:10.1108/14684520010341317.

Lybaert, N. (2002). On-line financial reporting: an analysis of the Dutch listed firms. The International Journal of Digital Accounting Research, 2(4),195-234. doi:10272/1495.

Lymer, A. (1999). The Internet and the future of corporate reporting in Europe. European Accounting Review, 2(2), 289-301. doi:10.1080/096381899336041.

Lymer, A., Debreceny, R., Gray, G. L., \& Rahman, A. (1999). Business Reporting on the Internet. [IASC Research Report].

Lymer, A., \& Tallberg, A. (1997). Corporate reporting and the internet - a survey and commentary on the use of the WWW in corporate reporting in the UK and Finland. In Annual Congress of the European Accounting Congress, Graz, Austria.

Ma, Z., Pant, G., \& Sheng, O. R. L. (2011). Mining competitor relationships from online news: A network-based approach. Electronic Commerce Research and Applications, 10(4), 418-427. doi:10.1016/j.elerap.2010.11.006.

Ma, Z., Sheng, O. R. L., \& Pant, G. (2009). Discovering company revenue relations from news: A network approach. Decision Support Systems, 47(4), 408-414. doi:10.1016/j.dss.2009.04.007. 
Marston, C. (2003). Financial reporting on the internet by leading Japanese companies. Corporate Communication: An International Journal, 8(1), 23-34. doi:10.1108/13563280310458894.

Marston, C., \& Leow, C. Y. (1998). Financial reporting on the Internet by leading UK companies. In $21^{\text {st }}$ Annual Congress of the European Accounting Association Antwerp Belgium.

Marston, C., \& Polei, A. (2004). Corporate reporting on the Internet by German companies. International Journal of Accounting Information System, 5(3), 285-311. doi:10.1016/j.accinf.2004.02.009.

McDonald, R., \& Lont, D. (2001). Financial Reporting on the Web - A 2001 Review. Chartered Accountants Journal, 64-68.

Mirshekary, S., \& Saudagaran, S. M. (2005). Perceptions and characteristics of financial statements users in developing countries: Evidence from Iran. Journal of International Accounting Auditing \& Taxation, 14(1), 33-54. doi:10.1016/j.intaccaudtax.2005.01.001.

Moghadam, H. M., Akhavansaffar, M., Bakhshaei, Z., \& MirHosseini, S. Y. (2013). Effect of investment in information technology system on providing desired services of accounting information system. Elixir International Journal, 55A, 13268-13273.

Mohd Isa, R. (2006). Graphical Information in Corporate Annual Report: A Survey of Users and Preparers Perception. Journal of Financial Reporting \& Accounting, 4(1), 39-60. doi:10.1108/19852510680001583.

Moradi, M., Salehi, M., \& Arianpoor, A. (2011). A study of the reasons for shortcomings in establishment of internet financial reporting in Iran. African Journal of Business Management, 5(8), 3312-3321.

Moreo, A., Romero, M., Castro, J. L., \& Zurita, J. M. (2012). Lexicon-based Commentsoriented News Sentiment Analyzer system. Expert Systems with Applications, 39(10), 9166-9180. doi:10.1016/j.eswa.2012.02.057.

Mostafa, M. M. (2013). More than words: Social networks' text mining for consumer brand sentiments. Expert Systems with Applications, 40(10), 4241-4251. doi:10.1016/j. eswa.2013.01.019.

Nassirtoussi, A. K., Aghabozorgi, S., Wah, T. Y., \& Ling Ngo, D. C. (2014). Text mining for market prediction: A systematic review. Expert Systems with Applications, 41(16), 7653-7670. doi:10.1016/j.eswa.2014.06.009.
Ojah, K., \& Mokoaleli-Mokoteli, T. (2012). Internet financing reporting, infrastructures and corporate governance: An international analysis. Development Finance, 2(2), 69-83. doi:10.1016/j.rdf.2012.04.001.

Oyelere, P., Laswad, F., \& Fisher, R. (2003). Determinants of internet financial reporting by New Zealand companies. Journal of International Financial Management and Accounting, 14(1), 26-61. doi:10.1111/1467-646X.00089.

Paranjape-Voditel, P., \& Deshpande, U. (2013). A stock market portfolio recommender system based on association rule mining. Applied Soft Computing, 13(2), 1055-1063. doi:10.1016/j.asoc.2012.09.012.

Pervan, I. (2006). Voluntary financial reporting on the internet- analysis of the practice of stock-market listed Croatian and Slovene joint stock companies. Financial Theory and Practice, 30(1), 1-27.

Pervan, I., \& Sabljic, M. (2011). Voluntary internet financial reporting in croatia - analysis of trends and influential factors. The Business Review, 17(2), 213-219.

Petravick, S., \& Gillett, J. (1996). Financial reporting on the World Wide Web. Management Accounting: 26-29 July.

Pirchegger, B., \& Wagenhofer, A. (1999). Financial information on the Internet: a survey of the homepages of Austrian companies. The European Accounting Review, 8(2), 383-395. doi:10.1080/096381899336113.

Poon, P. L., Li, D., \& Yu, Y. T. (2003). Internet financial reporting. Information Systems Control Journal, 1(1-3).

PricewaterhouseCoopers. (2002). Market Readiness for Disclosure-Based Regulation, Highlights from the survey on the readiness of the Malaysian Capital Market participants for $D B R$. Kuala Lumpur: Securities Commission.

Ravi, K., \& Ravi, V. (2015). A survey on opinion mining and sentiment analysis: Tasks, approaches and applications. KnowledgeBased Systems, 89, 14-46. doi:10.1016/j. knosys.2015.06.015.

Robert, P. S., Zhang, Y., Huang, C. N., \& Chen, H. (2012). Evaluating sentiment in financial news articles. Decision Support Systems, 53(3), 458-464. doi:10.1016/j. dss.2012.03.001.

Sanchez, I. G., Dominguez, L. R., \& Alvarez, I. G. (2011). Corporate governance and strategic information on the internet. Accounting, Auditing 
\& Accountability Journal, 24(4), 471-501. doi:10.1108/09513571111133063.

Schumaker, R. P., \& Chen, H. (2009). A quantitative stock prediction system based on financial news. Information Processing \& Management, 45(5), 571-583. doi:10.1016/j.jpm.2009.05.001.

Sekaran, U. (2003). Research methods for business a skill building approach (4th ed.). USA: John Wiley \& Sons Inc.

Shiri, M., Salehi, M., \& Bigmoradi, N. (2013). Internet financial reporting: Case of Iran. Journal of Distribution Science, 11(3), 49-62. doi:10.15722/jds.11.3.201303.49.

Spaul, B. (1997). Corporate dialogue in the digital age. London: The Institute of Chartered Accountants in England and Wales.

Stoel, D., Havelka, D., \& Merhout, J. W. (2012). An analysis of attributes that impact information technology audit quality: a study of IT and financial audit practitioners. International Journal of Accounting Information System, 13(1), 60-79. doi:10.1016/j.accinf.2011.11.001.

Thorleuchter, D., \& Van den Poel, D. (2012). Predicting e-commerce company success by mining the text of its publicly-accessible website. Expert Systems with Applications, 39(17), 13026-13034. doi:10.1016/j.eswa.2012.05.096.

Talakokkula, A. (2015). A Survey on Web Usage Mining, Applications and Tools. Computer Engineering and Intelligent Systems, 6(2), 22-29.

Trites, G. (1999). The impact of technology on financial and business reporting. Canadian Institute of Chartered Accountants.

Urbanaviciene, V., Kaklauskas, A., \& Zavadskas, E. K. (2009). The conceptual model of construction and real estate negotiation. International Journal of Strategic Property Management, 13(21), 53-70. doi:10.3846/1648-715X.2009.13.53-70.

Valentinetti, D., \& Rea, M. A. (2012). IFRS taxonomy and financial reporting practices: The case of Italian listed companies. International Journal of Accounting Information System, 13(2), 163-180. doi:10.1016/j.accinf.2011.09.001.

Wallman, S. (1995). The future of accounting and disclosure in evolving world: the need for dramatic change. Accounting Horizon, 9(3), 81-91.

Wilmshurst, T. D., \& Frost, G. R. (2000). Corporate environmental reporting: $A$ test of legitimacy theory. Accounting, Auditing Accountability Journal, 13(1), 10-25. doi:10.1108/09513570010316126.
Xiao, J. Z., Jones, M. J., \& Lymer, A. (2005). A conceptual framework for investigating the impact of the internet on corporate financial reporting. The International Journal of Digital Accounting Research, 5(10), 131-169.

Xiao, J. Z., Yang, H., \& Chow, C. W. (2004). The determinants and characteristics of voluntary Internet-based disclosures by listed Chinese companies. Journal of Accounting and Public Policy, 23(3), 191-225. doi:10.1016/j. jaccpubpol.2004.04.002.

Zhang, X., Edwards, J., \& Harding, J. (2007). Personalised online sales using web usage data mining. Computers in Industry, 58(8-9), 772-782. doi:10.1016/j.compind.2007.02.004.

Zhang, X., Fuehres, H., \& Gloor, P. A. (2011). Predicting Stock Market Indicators Through Twitter "I hope it is not as bad as I fear". Procedia - Social and Behavioral Sciences, 26, 55-62. doi:10.1016/j.sbspro.2011.10.562.

Mohd Noor Azli Ali Khan, Ph.D. Universiti Teknologi Malaysia Faculty of Management Department of Accounting and Finance m-nazli@utm.my

Noor Azizi Ismail, Ph.D. Universiti Utara Malaysia College of Business Othman Yeop Abdullah Graduate School of Business azizi833@uum.edu.my

Abbas Mardani, Ph.D. Universiti Teknologi Malaysia

Faculty of Management

Department of Business Administration abbas@management.utm.my

Edmundas Kazimieras Zavadskas, Ph.D., DrSc. Vilnius Gediminas Technical University Faculty of Civil Engineering Research Institute of Smart Building Technologies edmundas.zavadskas@vgtu.It

Arturas Kaklauskas, Ph.D., DrSc. Vilnius Gediminas Technical University Faculty of Civil Engineering Department of Construction Economics and Property Management arturas.kaklauskas@gmail.com 


\title{
Abstract
}

\section{EMPIRICAL RESEARCH OF USERS' OPINIONS ON SELECTED ASPECTS IN INTERNET FINANCIAL REPORTING}

\author{
Mohd Noor Azli Ali Khan, Noor Azizi Ismail, Abbas Mardani, Edmundas \\ Kazimieras Zavadskas, Arturas Kaklauskas
}

This study investigates the perceptions of users of corporate annual reports in relation to selected aspects of internet financial reporting. This study also analyzes Web analytics (Web usage and Web content analytics) to discover financial and non-financial usage and content patterns from company websites and other sources of World data. The case studies submitted in this article partly demonstrates the developed Web analytics systems. To serve this purpose, a questionnaire was distributed to five user groups (academics, students, managers, bank officers and auditors). From the survey, the analysis indicates that attracting's foreign investors, promoting the company to a wider public, attract local investors and promote wider coverage are the four most important benefits of IFR to the company. The findings revealed that three main benefits to the users who collect financial information of companies via their website are: increases timeliness and efficiency in obtaining financial information, makes investment decision process easier and faster, and provides information about a company inexpensively. Preliminary findings suggested three factors that are perceived as important by responding firms to engage in IFR: enhance corporate image, company teller with the technology development, and competitors in the industry. The findings also revealed three factors that inhibit firms from engaging in IFR: required expertise from the company, need to keep information up to date to be of use and concern over security of information. The findings also suggested increased information and analysis, and global reach and mass communication as the most important advantages from financial reporting on the internet. On the other hand, security problems, and cost and expertise are the biggest disadvantages of placing financial information on the internet. Finally, plausible implications of the findings of the study are then presented and areas for future research are also proposed. Taken together, these research outcomes make an incremental contribution to the existing financial reporting literature by providing useful insights into our knowledge of IFR especially for emerging capital markets like Malaysia.

Key Words: Users' opinions, selected aspects, internet financial reporting, web analytics and Malaysia.

JEL Classification: M4.

DOI: 10.15240/tul/001/2017-2-011 